\title{
TERAPI EMOTIONAL FREEDOM TECHNIQUE MENURUNKAN NYERI POST SECTIO CAESAREA
}

\author{
Jojor Silaban \\ Prodi Dairi Poltekkes Kemenkes Medan \\ Email : silaban.jojor473@gmail.com
}

\begin{abstract}
Background. Every surgery will experience pain, ranging from mild pain to very severe pain. $93 \%$ of sectio caesarea (SC) patients experience moderate to severe pain using a visual analog scale (VAS). Pain causes disruption to sleep rest, limited to meeting needs such as self-care, baby care and bounding attachments. Pain is minimized by pharmacological and non-pharmacological approaches. One of them is Emotional Freedom Technique (EFT) therapy. Research purposes. Knowing the effect of EFT therapy on pain in post SC mothers in Sidikalang Regional Hospital. Research methods. This study used a quasi-experimental design with a one group pre-post test design approach. Data collection in the Mawar Room of Sidikalang Regional Hospital with a population of 298 people and a sample of 20 people with incidental sampling technique. Data were analyzed by different paired t test. Research result. Shows that the average pre-test pain in post SC mothers is moderate pain (46.45), and the average post-test pain is mild pain (32.45). Different test results paired t test, pre-test and posttest found 11,570>1,729 (t arithmetic $>t$ table). From the test results it was found that there are significantly different mean before and after EFT therapy. Conclusion. There is an effect of EFT therapy on pain in post SC mothers. Suggestion. So that health workers are willing and able to do EFT therapy to reduce post SC pain.
\end{abstract}

Keywords: Post Sectio Caesarea Pain, EFT Therapy

\begin{abstract}
ABSTRAK
Setiap pembedahan akan mengalami nyeri, mulai dari nyeri ringan sampai nyeri sangat berat. Terdapat $93 \%$ pasien sectio caesarea (SC) mengalami nyeri sedang sampai dengan berat dengan menggunakan skala analog visual (VAS). Nyeri menyebabkan gangguan istirahat tidur, terbatas memenuhi kebutuhan seperti perawatan diri, pengasuhan bayi dan bounding attachment. Nyeri diminimalkan dengan pendekatan farmakologis dan nonfarmakologis. Salah satunya adalah terapi Emotional Freedom Technique (EFT). Tujuan penelitian untuk mengetahui pengaruh terapi EFT terhadap nyeri pada ibu post SC di RSUD Sidikalang. Metode penelitian. Penelitian ini menggunakan desain quasi eksperimen dengan pendekatan one group pre-post test design. Pengumpulan data di Ruang Mawar RSUD Sidikalang dengan jumlah populasi 298 orang dan sampel 20 orang dengan teknik insidental sampling. Data dianalisis dengan uji beda Paired t test. Hasil penelitian. Menunjukkan bahwa rata-rata nyeri pre-test pada ibu post SC yaitu nyeri sedang (46.45), dan rata-rata nyeri post test adalah nyeri ringan (32.45). Hasil uji beda paired t test, pre-test dan post-test didapatkan 11.570>1.729 ( $\mathrm{t}$ hitung $>\mathrm{t}$ tabel). Artinya ada beda secara signifikan rerata sebelum dan sesudah diberikan terapi EFT. Kesimpulan. Ada pengaruh terapi EFT terhadap nyeri pada ibu post SC. Saran. Agar petugas kesehatan mau dan mampu melakukan terapi EFT untuk menurunkan nyeri post SC.
\end{abstract}

Kata Kunci : Nyeri post sectio caesarea, terapi EFT

\section{Latar Belakang}

Sekarang ini banyak ibu yang merasa begitu ketakutan untuk melahirkan secara alami atau persalinan melalui vagina. Mereka beranggapan bahwa proses persalinan normal lebih sakit atau nyeri dibanding dengan operasi seksio sesarea. Hal ini diketahui dari cerita atau pun pengalaman dari ibu-ibu yang merasakan nyeri persalinan normal. Padahal persepsi dan tingkat intensitas nyeri terhadap kemampuan pertahanan tubuh terhadap nyeri tergantung masing-masing orang. Persalinan seksio sesarea memang tidak dirasakan nyeri dalam proses melahirkan, hanya saja ketika efek penggunaan anestesi yang diberikan telah habis maka ibu akan mengalami nyeri.

Nyeri diartikan sebagai suatu keadaan yang tidak menyenangkan akibat terjadinya rangsangan fisik maupun dari serabut saraf dalam tubuh ke otak dan diikuti oleh reaksi fisik, fisiologis, maupun emosional. $^{(1)}$ Banyak faktor yang memengaruhi persepsi dan reaksi nyeri, diantaranya adalah sebagai berikut : lingkungan, keadaan umum, endorfin, faktor 
situasional, jenis kelamin, status emosi, pengalaman yang lalu, reaksi terhadap nyeri, ansietas dan kepribadian, budaya dan sosial, usia, arti nyeri, fungsi kognitif, kepercayaan. Nyeri terjadi karena akibat adanya stimulus nyeri antara lain : 1) fisik (termal, mekanik, elektrik); dan 2) kimia. Apabila ada kerusakan pada jaringan akibat adanya kontinuitas jaringan yang terputus, maka histamin, bradikinin, serotonin, dan prostaglandin akan diproduksi oleh tubuh. Zat-zat kimia ini akan menimbulkan rasa nyeri. Rasa nyeri ini diteruskan ke Central Nerve System (CSN) kemudian di transmisikan ke serabut tipe C yang menghasilkan sensasi seperti terbakar atau pada serabut tipe A yang menghasilkan nyeri, seperti tertusuk. ${ }^{(2)}$

Masalah fisiologis pada hari pertama paska seksio sesarea didominasi oleh nyeri pada area insisi operasi yaitu nyeri karena adanya gas di usus, dan nyeri karena adanya kontraksi otot-otot polos uterus (afterpain). Afterpain dirasakan lebih berat oleh klien pada hari pertama dibandingkan dengan hari kedua sampai dengan hari keempat. Klien dilaporkan 50\% mengalami nyeri sedang/berat pada hari pertama dan menurun menjadi $5 \%$ pada hari keempat. ${ }^{(2)}$

Nyeri dan rasa sakit yang berlebihan akan menimbulkan rasa cemas. Takut, cemas dan tegang memicu produksi prostaglandin sehingga timbul stress. Dengan adanya nyeri operasi seksio sesarea akan menyebabkan ibu tidak dapat atau terbatas dalam memenuhi kebutuhannya sehari-hari seperti perawatan diri dan pengasuhan bayinya. Ibu juga mengalami penurunan kemampuan bounding attachment pada bayinya. $^{(3)}$ Proses menyusui pada operasi seksio sesarea lebih sulit akibat ibu merasa tidak nyaman setelah operasi dan tidak segera dapat kontak dengan bayinya. ${ }^{(4)}$ Menurut Rukiyah \& Yulianti rasa sakit atau pun masalah stress pada ibu paska persalinan dapat menghambat produksi ASI. Dalam hal ini bayi tidak akan mendapat pengasuhan yang baik dan pemenuhan ASI menjadi terhambat oleh adanya luka. ${ }^{(5)}$ Proses persalinan dengan tindakan /operatif/ SC merupakan salah satu faktor penghambat dilakukannya bounding attachment. Disisi lain bounding attachment memiliki tujuan dan manfaat bagi bayi yaitu : membantu tumbuh kembang fisik, emosi dan intelektual seorang anak dari awal kehidupan hingga dewasa, bayi merasa dicintai dan diperhatikan, bayi merasa aman karena dekapan dari ibunya, merupakan awal dalam menciptakan dasar-dasar kepribadian yang positif. ${ }^{(6)}$

Emotional freedom technique (EFT) adalah model terapi energi psikologis yang dikembangkan oleh Gary Craig pada tahun 1990 dengan menggabungkan ilmu akupunktur dan mind body medicine. Emotional freedom technique (EFT) disebut juga dengan versi emosional akupunktur. ${ }^{(7)}$

Berdasarkan hasil penelitian Rusdiana tahun 2016 di RSUD Labuang Baji Makassar ada Pengaruh Hypno-Eft (Emotional Freedom Technique) Terhadap Skala Nyeri Pada Pasien Post Operasi Ortopedi Yang Mengalami Frakture Di RSUD Labuang Baji
Makassar, menunjukkan hasil uji statistik didapatkan nilai $\mathrm{p}=<0,001(\mathrm{p}=<0,05)$, yang berarti ada perbedaan bermakna skala nyeri responden sebelum dan sesudah dilakukan hypno-eft selama 3 hari. ${ }^{(8)}$ Hasil survei awal Peneliti pada bulan Mei 2019 di Ruang Mawar RSUD Sidikalang yaitu jumlah ibu yang mengalami persalinan seksio sesarea sebanyak 17 (tujuh belas) orang ibu. Terdapat 3 (tiga) orang mengalami nyeri ringan, 9 (sembilan) orang ibu mengalami nyeri sedang, dan terdapat 5 (lima) orang ibu mengalami nyeri berat . Selanjutnya Peneliti menanyakan apakah terapi emotional freedom technique (EFT) pernah diberikan tenaga dalam manajemen nyeri. Hasil wawancara menunjukkan semua ibu post seksio sesarea mengatakan tidak pernah menerima terapi EFT dilakukan bidan maupun tenaga kesehatan lainnya. Selanjutnya Peneliti melakukan wawancara terhadap bidan yang ada di Ruang Mawar tentang upaya penurunan nyeri pada ibu post seksio sesarea biasanya dilakukan dengan pemberian obat analgetik yang telah diresepkan dokter. Pemberian pengobatan non farmakologis juga dilakukan seperti teknik relaksasi, distraksi. Namun terapi EFT tidak pernah dilakukan. Hal ini dikarenakan kurangnya pemahaman, dan pengetahuan tentang terapi EFT.

Berdasarkan uraian diatas, Peneliti tertarik untuk melakukan penelitian tentang Pengaruh Terapi Emotional Freedom Technique Terhadap Penurunan Nyeri Post Operasi Sectio Caesarea di RSUD Sidikalang.

\section{Metodologi Penelitian}

Penelitian ini adalah studi kasus dengan menggunakan desain quasi eksperimen dengan pendekatan one group pre post test design. Penelitian ini hanya menguji satu kelompok subyek dimana kelompok tersebut diobservasi sebelum dilakukan intervensi kemudian diobservasi lagi sesudah intervensi. ${ }^{(9)}$

Penelitian ini dilaksanakan di ruang Mawar RSUD Sidikalang pada mulai bulan Mei sampai Juni 2019. Populasi penelitian adalah ibu post sectio caesarea berjumlah 298 orang. Teknik penentuan sampel adalah Non probability sampling jenis insidental sampling. Jumlah sampel yang digunakan sebagai subyek penelitian ini dihitung dengan rumus menurut Sastroasmoro dan Ismael : ${ }^{(10)}$

$$
\mathrm{n}=\frac{\mathrm{N} \cdot \mathrm{Z}_{1-\alpha / 2}^{2} \mathrm{P}(1-\mathrm{P})}{(\mathrm{N}-1) \mathrm{d}^{2}+\mathrm{N} \cdot \mathrm{Z}_{1-\alpha / 2}^{2} \mathrm{P}(1-\mathrm{P})}
$$

Keterangan :

$$
\begin{array}{lll}
\mathrm{N} & \text { : Besar populasi } & \\
\mathrm{n} & \text { : Besar sampel } & \\
\mathrm{d} & \text { : Kesalahan (absolut) } & \text { yang dapat ditolerir } \\
\text { (yang } & \multicolumn{1}{c}{\text { diinginkan }} & \text { Peneliti } \\
& 15 \%) & \text { yaitu } \\
\mathrm{P} & \text { : Harga proporsi di populasi yaitu } 50 \%(0.5)
\end{array}
$$
$\mathrm{Zl}-\alpha / 2$ : Nilai distribusi normal baku (tabel Z) pada $\alpha$ tertentu yaitu 1,96

$$
\mathrm{n}=\frac{298 \cdot 1 \cdot 96 \cdot 0,5(1-0,5)}{(298-1)(0,15)^{2}+1.96 \cdot 0,5(1-0,5)}
$$




$$
\begin{aligned}
& n=\frac{146,02}{6,68+0,49} \quad \text {, maka } n=\frac{146,02}{7,16} \\
& n=20,39 \\
& n=20
\end{aligned}
$$

Berdasarkan rumus tersebut maka jumlah sampel penelitian ini adalah 20 (dua puluh) orang.Sampel dalam penelitian ini disebut juga dengan istilah subjek penelitian. Pengumpulan data dilakukan dengan cara wawancara pre test, perlakuan dan post test. Peneliti mengumpulkan informasi tentang skala nyeri akibat post sectio caesarea yang dialami ibu sebelum diberikan intervensi terapi emotional freedom technique (EFT) (pre test), kemudian peneliti melakukan intervensi terapi EFT yang dilakukan sesuai dengan prosedur tindakan menurut Sutja ${ }^{(1)}$ dilakukan sebanyak 2 kali durasi 5-10 menit dan interval 10 menit. Setelah dilakukan intervesi dilakukan evaluasi yang disebut dengan post test dengan menggunakan kuesioner yang sama pada pre test. Pengolahan data untuk mendapatkan pengaruh intervensi terapi EFT terhadap nyeri post sectio caesarea ditentukan jika rata-rata skala nyeri menurun dari sebelum perlakuan (pre test) dan sesudah perlakuan (post test), analisis paired t test jika $t$ hitung lebih besar dari $t$ table.

\section{Hasil Penelitian}

Dalam penelitian ini didapatkan subyek penelitian sebanyak 20 (dua puluh) orang ibu yang mengalami nyeri post sectio caesarea yang sesuai dengan kriteria yang ditetapkan. Berikut gambaran demografi subyek penelitian dapat dilihat secara lengkap pada tabel dibawah ini :

Tabel 1 : Distribusi Karakteristik Subyek Penelitian Pengaruh Terapi EFT Terhadap Penurunan Nyeri Pada ibu Post Sectio Caesarea di

\begin{tabular}{|c|c|c|c|}
\hline No & Karakteristik & Frekuensi & $\%$ \\
\hline \multirow[t]{5}{*}{1.} & Umur & & \\
\hline & $\begin{array}{l}\text { Usia muda } \leq 20 \\
\text { Tahun }\end{array}$ & 1 & $5 \%$ \\
\hline & $\begin{array}{l}\text { Usia produktif } 21- \\
35 \text { tahun }\end{array}$ & 12 & 60.00 \\
\hline & Usia tua $>35$ tahun & 7 & 35.00 \\
\hline & Total & 20 & 100.0 \\
\hline \multirow[t]{5}{*}{2.} & Pekerjaan & & \\
\hline & Petani & 14 & 70.00 \\
\hline & $\begin{array}{l}\text { Ibu Rumah Tangga } \\
\text { (IRT) }\end{array}$ & 3 & 15.00 \\
\hline & Wiraswasta & 3 & 15.00 \\
\hline & Total & 20 & 100.0 \\
\hline \multirow[t]{4}{*}{3.} & Pendapatan & & \\
\hline & $\begin{array}{l}<\text { Rp.2.307.801 } \\
\text { (Kurang) }\end{array}$ & 14 & 70.00 \\
\hline & $\begin{array}{l}\geq \text { Rp.2.307.801 } \\
\text { (Cukup) }\end{array}$ & 6 & 30.00 \\
\hline & Total & 20 & 100.0 \\
\hline 4. & Pendidikan & & \\
\hline
\end{tabular}
Ruang Mawar Rumah Sakit Umum Daerah

\begin{tabular}{|c|c|c|c|}
\hline & Tidak sekolah & 1 & 05.00 \\
\hline & SD & 2 & 10.00 \\
\hline & SMP & 2 & 10.00 \\
\hline & SMA & 13 & 65.00 \\
\hline & Perguruan Tinggi & 2 & 10.00 \\
\hline & Total & 20 & 100.0 \\
\hline \multirow[t]{4}{*}{5.} & $\begin{array}{l}\text { Dukungan } \\
\text { keluarga }\end{array}$ & & \\
\hline & Adekuat & 18 & 90.00 \\
\hline & Tidak adekuat & 2 & 10.00 \\
\hline & Total & 20 & 100.0 \\
\hline \multirow[t]{2}{*}{6.} & Trauma persalinan & & \\
\hline & Tidak ada & 20 & 100.0 \\
\hline \multirow[t]{2}{*}{7.} & $\begin{array}{l}\text { Komplikasi } \\
\text { kehamilan }\end{array}$ & & \\
\hline & Tidak ada & 20 & 100.0 \\
\hline
\end{tabular}
Sidikalang
Berdasarkan Tabel 1 dapat dilihat gambar karakteristik subyek penelitian usia produktif sebanyak 13 (tiga belas) orang $(65.00 \%)$ dan usia tua sebanyak 7 (tujuh) orang (35.00\%), pekerjaan sebagai IRT 3 (tiga) orang $(15.00 \%)$, Petani sebanyak 14 (empat belas) orang $(70.00 \%)$, dan Wiraswasta 3 (tiga) orang $(15.00 \%)$, pendapatan kurang sebanyak 14 (empat belas) orang $(70.00 \%)$, pendapatan cukup sebanyak 6 (enam) orang $(30.00 \%)$, pendidikan tidak sekolah sebanyak 1 (satu) orang $(05.00 \%)$, tamatan SD 2 (dua) orang $(10.00 \%)$, SMP 2 (dua) orang $(10.00 \%)$, SMA 13 (tiga belas) orang $(65.00 \%)$, perguruan tinggi sebanyak 2 (dua) orang (10.00\%) dukungan keluarga adekuat 20 (dua puluh) orang (100.0\%), tidak ada trauma persalinan 20 (dua puluh) orang (100.0\%), tidak ada komplikasi/ penyulit kehamilan 20 (dua puluh) orang (100.0\%).

\section{Gambaran Nyeri Sebelum dan Sesudah Dilakukan Terapi Emotional Freedom Technique}

Sesuai dengan prosedur penelitian, maka penelitian melakukan pre test kepada subyek untuk mengetahui skala nyeri sebelum diberikan perlakuan. Untuk mengetahui skala nyeri, peneliti melakukan wawancara dan observasi 20 pertanyaan. Jenis pertanyaan berupa interval atau 0-4. 0 ; 0 : tidak ada, 1 : ringan, 2 : sedang, 3 : berat, 4 : sangat berat. Klasifikasi nyeri terdiri dari skor 0-16 : tidak ada nyeri, skor 17-32 : nyeri ringan, skor 33-48 : nyeri sedang, skor 49-64 : nyeri berat, skor 65-80 : nyeri sangat berat. Selanjutnya peneliti melakukan intervensi EFT. Terapi EFT dilakukan kepada subyek sebanyak 2 kali, satu periode membutuhkan waktu dengan durasi 5-10 menit, interval perlakuan terapi EFT adalah 10 menit. Sesudah intervensi dilakukan selanjutnya peneliti melakukan evaluasi yang disebut dengan post test sama halnya dengan pre test. Tabel di bawah ini menggambarkan skala nyeri subjek sebelum dan sesudah dilakukan terapi EFT.

Tabel 2 : Gambaran Skala Nyeri Subyek Penelitian Sebelum Dan Sesudah Perlakuan Terapi EFT Pada 
Nyeri Post Sectio Caesarea Di Ruang Mawar Rumah Sakit Umum Daerah Sidikalang

\begin{tabular}{|r|lllll|} 
No & $\begin{array}{l}\text { Skala } \\
\text { nyeri }\end{array}$ & \multicolumn{2}{l}{ Pre test } & \multicolumn{2}{l}{ Post test } \\
\hline 1. $\begin{array}{l}\text { Tidak } \\
\text { Nyeri }\end{array}$ & 0 & $\%$ & 2 & 10.00 \\
\hline 2. $\begin{array}{l}\text { Nyeri } \\
\text { Ringan }\end{array}$ & 2 & 10.00 & 8 & 40.00 \\
\hline 3. $\begin{array}{l}\text { Nyeri } \\
\text { Sedang }\end{array}$ & 8 & 40.00 & 8 & 40.00 \\
\hline 4. $\begin{array}{l}\text { Nyeri } \\
\text { Berat }\end{array}$ & 10 & 50.00 & 2 & 10.00 \\
\hline Total & & 20 & 100.0 & 20 & 100.0 \\
\hline
\end{tabular}

Berdasarkan Tabel 2 dapat dilihat bahwa nyeri yang dialami subyek penelitian sebelum perlakukan terapi EFT adalah nyeri ringan sebanyak 2 (dua) orang (10.00\%), nyeri sedang 8 (delapan) orang $(40.00 \%)$ dan nyeri berat 10 (sepuluh) orang $(50.00 \%)$. Selanjutnya dapat dilihat bahwa nyeri yang dialami subyek penelitian sesudah perlakuan terapi EFT adalah 2 (dua) orang tidak mengalami nyeri $(10.00 \%), 8$ (delapan) orang nyeri ringan $(40.00 \%), 8$ (delapan) orang nyeri sedang $(40.00 \%)$ dan 2 (dua) orang mengalami nyeri berat $(10.00 \%)$. Hasil penelitian menunjukkan bahwa terapi EFT berpengaruh menurunkan nyeri post sectio caesarea sebanyak satu tingkatan.

Tabel 3 : Rerata Skala Nyeri Sebelum dan Sesudah Dilakukan Terapi EFT

\begin{tabular}{lllll} 
Subjek & Pre & Post & Mean & \\
\cline { 4 - 5 } & & & Pre & Post \\
1 & 57 & 33 & 46.45 & 32.45 \\
2 & 43 & 19 & & \\
3 & 53 & 41 & & \\
4 & 42 & 31 & & \\
\hline 5 & 49 & 36 & & \\
6 & 41 & 26 & & \\
\hline 7 & 57 & 45 & & \\
8 & 62 & 59 & & \\
\hline 9 & 42 & 32 & & \\
10 & 60 & 41 & & \\
11 & 53 & 34 & & \\
12 & 43 & 24 & & \\
13 & 17 & 8 & & \\
14 & 63 & 48 & & \\
\hline 15 & 49 & 37 & & \\
\hline 16 & 36 & 20 & \\
\hline 17 & 34 & 19 & \\
\hline 18 & 47 & 30 & \\
\hline 19 & 24 & 16 & \\
\hline 20 & 57 & 50 & \\
\hline Total & 929 & 649 & \\
\hline
\end{tabular}

skala nyeri sebelum perlakuan adalah 46,45 dan sesudah perlakuan menjadi 32,45 . Artinya didapatkan bahwa ada penurunan secara signifikan skala nyeri sebelum (pre) dan sesudah (post) diberikan terapi emotional freedom technique (EFT) pada ibu nyeri post sectio caesarea. Dengan kata lain ada pengaruh pemberian terapi emotional freedom technique (EFT) terhadap nyeri post sectio caesarea.

\section{Pembahasan}

Hasil penelitian menunjukkan rata-rata skor nyeri sebelum (pre test) diberikan perlakuan terapi EFT sebesar 46.45 atau sama dengan kategori nyeri sedang dan sesudah diberikan perlakukan (post test) sebesar 32.45 atau sama dengan kategori nyeri ringan. Dapat dianalisa bahwa terjadi penurunan skala nyeri satu tingkatan. Dengan demikian dapat disimpulkan bahwa terapi emotional freedom technique (EFT) berhasil menurunkan nyeri pada ibu post sectio caesarea.

Untuk mengetahui hasil uji perbandingan skala nyeri pasien nyeri pre dan post pada ibu nyeri post sectio caesarea. Selanjutnya dilakukan analisis paired $t$ test didapatkan harga $t$ hitung 11.570 dibandingkan dengan $t$ tabel dengan $\mathrm{df}=\mathrm{n}-1,19-1=19$, sehingga $t=1.729$ dalam hal ini $11.570>1.729(t$ hitung $>t$ tabel). Dari hasil uji beda dengan paired $t$ test didapatkan ada beda secara signifikan antara ratarata sebelum (pre) dan sesudah (post) diberikan terapi emotional freedom technique (EFT) pada ibu nyeri post sectio caesarea. Dengan demikian ada pengaruh terapi EFT terhadap nyeri post sectio caesarea.

Nyeri adalah pengalaman sensori dan emosional yang tidak menyenangkan akibat kerusakan jaringan yang aktual atau potensial. Nyeri ini disebabkan oleh adanya peregangan otot uterus dan adanya insisional pada jaringan abdomen setelah efek anestesi hilang. ${ }^{(11)}$ Banyak faktor yang memengaruhi persepsi dan reaksi nyeri, diantaranya adalah sebagai berikut : usia, jenis kelamin, kebudayaan, makna nyeri, perhatian, ansietas, keletihan, pengalaman sebelumnya, gaya koping, dukungan keluarga dan sosial. ${ }^{(4)}$ Faktor-faktor tersebut dapat meningkatkan atau menurunkan persepsi nyeri pasien, meningkat dan menurunnya toleransi terhadap nyeri dan pengaruh sikap respon terhadap nyeri. ${ }^{(11)}$

Hasil penelitian menunjukkan terdapat 18 (delapan belas) orang mengalami penurunan nyeri satu skala dan 2 (dua) orang tidak mengalami penurunan skala nyeri. Kegagalan terapi atau intervensi, menurut analisa Peneliti, kemungkinan disebabkan oleh 2 (dua) hal atau faktor pengaruh yaitu dukungan keluarga yang tidak adekuat dan kesalahan persepsi.

Terapi EFT adalah suatu bentuk emosional dari akupunktur tanpa menggunakan jarum, hanya mengetuk dengan 2 (dua) jari untuk merangsang titiktitik meridian tubuh dari klien sambil klien "tune in" kepada masalahnya. ${ }^{(1)}$ Saat seseorang mengalami 
gangguan emosi maka terjadilah gangguan di sistem energi tubuh. Pemblokiran yang terjadi pada aliran energi positif hanya dapat dibuka melalui ketukan pada titik meridian yang terkoneksi dalam sirkuit meridiannya. Mengetuk titik meridian energi yang terpilih yang dapat menghapus emosi negatif. Ketukanketukan tersebut bertujuan untuk menyeimbangkan energi meridian dalam tubuh ketika terjadi gejalagejala kemunduran fisik dan emosional yang mengganggu. EFT melakukan ketukan untuk melancarkan lagi energi tubuh sehingga mengakibatkan emosi kembali harmonis.

Berdasarkan hasil penelitian Ma'rifah, Handayani, Dewi tentang Pengaruh Pemberian Therapi SEFT Terhadap Penurunan Nyeri Pada Seksio Sesarea Di RSUD Margono Soekardjo Purwokerto menunjukkan bahwa hasil penelitian pada kelompok kontrol nilai korelasi sebesar 0,431 dan nilai $\mathrm{R}$-square sebesar $18,6 \%$, sedangkan pada kelompok eksperiment SEFT nilai korelasi sebesar 0,874 dengan nilai Rsquare sebesar $76 \% .^{(12)}$ Sejalan dengan hasil penelitian Rusdiana tahun 2016 di RSUD Labuang Baji Makassar Ada Pengaruh Hypno-Eft (Emotional Freedom Technique) Terhadap Skala Nyeri Pada Pasien Post Operasi Ortopedi Yang Mengalami Fraktur Di RSUD Labuang Baji Makassar menunjukkan hasil uji statistik didapatkan nilai $\mathrm{p}=<0,001(\mathrm{p}=<0,05)$, yang berarti ada perbedaan bermakna skala nyeri responden sebelum dan setelah dilakukan hypno-eft selama 3 hari. ${ }^{(8)}$ Hasil penelitian ini juga sejalan dengan hasil penelitian Brahmantia \& Huriah tahun 2016 tentang Pengaruh Spiritual Emotional Freedom Technique Terhadap Penurunan Nyeri Dan Kecemasan Pada Pasien Pasca Bedah TURP Di RSUD dr. Soekardjo Tasikmalaya. Hasil penelitian penulis didapatkan ada pengaruh EFT terhadap penurunan nyeri pada pasien pasca operasi bedah TURP. Hasil paired t test analisis nyeri pada kelompok intervensi dan kelompok kontrol didapatkan $p$ value, 0,001, hasil uji independent t-test variabel nyeri nilai $\mathrm{p}=0,2>0,005$. $^{(13)}$

\section{Keterbatasan Penelitian}

Penelitian yang dilakukan oleh peneliti masih memiliki beberapa keterbatasan. Adapun keterbatasan dalam penelitian ini adalah :

1. Desain penelitian yang digunakan tanpa kelompok control, sehingga peneliti hanya bisa membandingkan hasil pre test dan post test.

2. Jumlah sampel dalam penelitian ini sudah sesuai dengan jumlah minimal sampel yang dibutuhkan, namun kemungkinan penelitian ini akan menghasilkan data yang lebih baik lagi jika dilakukan dengan populasi yang lebih besar dengan jumlah yang sampel yang lebih banyak lagi.

\section{Kesimpulan}

Hasil penelitian menunjukkan ada pengaruh terapi EFT terhadap penurunan nyeri post sectio caesarea. Rumah sakit hendaknya membuat program pelatihan mengenai terapi terapi untuk menangani nyeri dengan pendekatan non farmakologis secara khusus dengan menerapkan terapi EFT terhadap asuhan keperawatan nyeri post sectio caesarea sehingga penanganan farmakologis dapat diminimalkan karena mempunyai efek samping terhadap kesehatan.

\section{DAFTAR PUSTAKA}

1. Akmal, Sutja. Emotional Freedom Technique. Bandung: Alfabeta. 2018.

2. Solehati, Kosasih. Relaksasi. Bandung: Refika Aditama. 2017.

3. Maryunani, A. Asuhan Pada Ibu Dan Masa Nifas (Post Partum). Jakarta: TIM. 2011.

4. Judha. Sudarti. Fauziah. Teori Pengukuran Nyeri \& Nyeri Persalinan. Yogyakarta: Nuha Medika. 2012

5. Rukiyah dan Yulianti. Buku Saku Asuhan Kebidanan Pada Ibu Masa Nifas. Jakarta: TIM. 2018

6. Rukiyah. Yulianti. Maemunah. Susilawati. Asuhan Kebidanan II (Persalinan). Jakarta: TIM. 2011.

7. Smeltzer SC. Bare BG. Buku Ajar Keperawatan Medikal Bedah. Brunner \& Suddart. Edisi : 8 volume 1. Alih bahasa Waluyo A, Karyasa I Julia, Kuncara, Asih Y. Jakarta: EGC. 2002.

8. Rusdiana. Hypno - EFT ( Emotional Freedom Technique) Terhadap Skala Nyeri Pada Pasien Post Operasi Ortopedi. Makassar: Universitas Islam Negeri Alauddin Makassar. repositori.uinalauddin.ac.id. 2016. Diakses tanggal 22 Maret 2019, Pukul 15.00 WIB.

9. Setiadi. Konsep \& Penulisan Riset Keperawatan. Yogyakarta: Graha Ilmu. 2007

10. Sastroasmoro dan Ismael. Dasar- Dasar Metodologi Klinis. Edisi Ke-3. Jakarta: Sagung Seto. 2008.

11. Padila. Keperawatan Maternitas. Jakarta : EGC. 2014.

12. Ma'rifah. Handayani. Dewi. Pengaruh Pemberian Therapi Spiritual Emotional Freedom Technique Terhadap Penurunan Nyeri Pasien Seksio Sesarea Di RSUD Margono Soedordjo Purwokerto. http://repository.umy.ac.id/NASKAH PUBLIK ASLI. 2015 Diakses Tanggal 08 Juli 2019, Pukul $15.58 \mathrm{WIB}$

13. Brahmantia dan Huriah. Pengaruh Spritual Emotional Freedom Technique (SEFT) Terhadap Penurunan Nyeri Dan Kecemasan Pada Pasien Pasca Bedah Transurethral Resection Prostate (TURP) Di RSUD dr. Soekardjo Kota Tasikmalaya. repository.umy.ac.id. 2016. Diakses tanggal 22 Maret 2019, Pukul 19.39 WIB 